\title{
Patterns of diatom treatment in two coexisting species of filter-feeding freshwater gastropods
}

\author{
T.Ya. Sitnikova ${ }^{(1), \star}$, G.V. Pomazkina ${ }^{(1)}$, T.A. Sherbakova ${ }^{(1)}$, N.V. Maximova ${ }^{(1)}$, \\ I.V. Khanaev ${ }^{(1)}$, Y.S. Bukin ${ }^{(1)}$
}

Received October 1, 2013

Revised January 3, 2014

Accepted January 23, 2014

Key-words:
Gastropoda,
large/small
diatom cell,
frustule
destruction,
trophic
partitioning,
food web

Key-words: Gastropoda, large/small diatom cell, frustule destruction, partitioning, food web

\section{ABSTRACT}

To assess trophic partitioning among sympatric gastropod species in ancient lakes, we quantified diatoms in the guts of two coexistent Baikal gastropod species and tested for differences in species, size, and fracturing of large and small diatoms by taenioglossan radulae. In May 2010, the diatom Synedra acus dominated the littoral phytoplankton and gut contents of Baicalia turriformis and Teratobaikalia ciliata (Baicaliidae), both inhabiting the rocky Baikal littoral. In laboratory experiments, both ctenidial filter-feeding gastropods were fed with two diets of cultivated Synedra acus of different cell sizes: $>150 \mu \mathrm{m}$ and $<100 \mu \mathrm{m}$. Field and laboratory studies revealed intact diatom cells (often with green chromatophores) and fragmented frustules of diatoms $<60 \mu \mathrm{m}$ in the guts of both species. The two baicaliids varied in the number of ingested microalgae. In addition, they exhibited significantly different efficiencies for breaking large diatoms; $B$. turriformis broke large diatoms into more fragments than T. ciliata. The differences in the utilization of large and small diatoms by gastropods are discussed in terms of the relationships among coexisting species. Small diatom survival is considered from the view of interactions between producers and their consumers in the freshwater food web.

\section{RÉSUMÉ}

Modes d'utilisation des diatomées par deux espèces coexistantes de gastéropodes d'eau douce se nourrissant par filtration

Mots-clés:
gastropode,
grande/petite
cellule
de la diatomé,
destruction
de la frustule,
partitionnement
trophique,
chaîne trophique

Mots-clés : gastropode, grande/petite cellule partitionnement chaîne trophique

Les espèces cténidiales se nourrissant par filtration Baicalia turriformis et Teratobaikalia ciliata ( Caenogastropoda : Hydrobioidea ) coexistent dans la zone littorale rocheuse du lac Baïkal. Elles s'alimentent sur les diatomées benthiques et les planctoniques sédimentées. Des diatomées intactes, généralement de plus petite taille sont contenues dans leurs particules de nourriture et les excréments avec des frustules cassées et vidées en large majorité. Nous avons examiné la différence, le cas échéant, entre les espèces dans la façon de briser par la radula les grandes et petites diatomées. La diatomée Synedra acus domine le phytoplancton littoral, en mai 2010, ainsi que les diatomées trouvées dans le contenu intestinal des escargots récoltés à l'époque. Dans des expériences de laboratoire, les deux espèces ont été nourries avec des $S$. acus cultivées de différentes tailles de cellule : les plus grandes de $150 \mu \mathrm{m}$ et les plus petites de taille inférieure à $100 \mu \mathrm{m}$. Les frustules de diatomées entières et brisées trouvées dans le bol alimentaire extraites de l'intestin antérieur ont été comptées sous un microscope

(1) Limnological institute of the Siberian Branch of the Russian Academy of Sciences, Ulan- Batorskaya str., 3, 664033 Irkutsk, Russia

* Corresponding author: sit@lin.irk.ru 
optique. Les études de terrain et de laboratoire ont montré que des diatomées de taille inférieure à $60 \mu \mathrm{m}$ avec frustules intactes et souvent avec chromatophores verts sont observées en permanence dans les particules alimentaires et dans les matières fécales des gastéropodes. Les deux baicaliidés varient dans la composition des espèces de diatomées ingérées. B. turriformis consomme un ordre de grandeur de plus des cellules de microalgues que $T$. ciliata. Les espèces diffèrent significativement dans l'efficacité avec laquelle elles cassent les diatomées.

\section{INTRODUCTION}

More than 180 gastropod species are known to inhabit Lake Baikal and its warm bays; $60 \%$ of them are found nowhere else in the world and are considered Baikal endemics. The caenogastropods of the Baicaliidae family (or subfamily according to Bouchet et al., 2005) are the most significant species flock among Baikal endemics. The occurrence of species flocks of endemic Baikal gastropods is regarded as an adaptive radiation to different habitats in shallow and deep water zones of the lake (Kozhov, 1936; Starobogatov and Sitnikova, 1990; Peretolchina et al. , 2007). Repeated and/or simultaneous colonization of the same habitats have led to the coexistence of several closely related species. For example, 10 of the 40 known species of the family Baicaliidae occur together on the rocky littoral of the lake (Sitnikova et al., 2010; our data).

It is known that one of the mechanisms of gastropod speciation in the world's ancient lakes is divergent adaptation to different trophic resources among sympatric species (e.g., Michel, 1994, 2000; von Rientelen et al., 2004; 2012; Glaubrecht and von Rientelen, 2008; Sitnikova et al., 2012). Sitnikova and colleagues demonstrated that five sympatric species of Baikal gastropods inhabiting the rocky littoral obtain sufficient amounts of food, mostly from seston, and they exhibit significant differences in diets, the stable isotopes $\delta^{13} \mathrm{C}$ and $\delta^{15} \mathrm{~N}$, and radular tooth morphology, which is evidence for food resource partitioning (Sitnikova et al., 2012). Diatoms are the main dietary component of Baikal gastropods regardless of feeding mechanisms - scrapping and/or filtering 4 (Roepstorf et al., 2003; Shirokaya, 2003; Sitnikova et al., 2012). Diatoms are a necessary and preferred food for many grazing marine and freshwater gastropods (Tsikhon-Lukanina, 1987; Dillon, 2000; Hernández \& Siqueiros-Beltrones, 2010; Riera, 2010; Zhang et al., 2010; etc.).

A diatom frustule consists of two nested valves composed of biogenic silica and covered on the outside by glycoprotein mucus. To digest cellular proteins, carbohydrates and lipids in ingested diatoms, snails have to mechanically destroy the frustules. The hardness of the frustules is comparable to the strength of the cortical bone in vertebrates (Hamm et al., 2003). The exposure of the silica cell wall to destructive action by herbivorous predators with teeth, mandibles and gizzards stimulated the evolution of protective mechanisms (Hamm, 2005; Finkel and Kotrc, 2010) and resulted in an abundance of sizes, shapes, degrees of silicification and densities of ornamentation of diatom valves. Base on the diversity of frustules morphology only, the number of diatom species exceeds 100000 (Round et al., 1990).

Snails usually digest only a part of consumed microalgae, including diatoms. In the depositfeeding gastropods Batillaria attrantaria and Cerithidea californica about $20 \%$ of chlorophyll pigments from ingested diatoms are found in feces (Whitlatch and Obrebski, 1980). Similarly, the photosynthetic activity of freshwater Lymnaea elodes feces was $77-79 \%$ that of ungrazed algae per unit mass (Cucker, 1983). Investigations into gastropod stomach contents showed that most diatom cells were broken and empty, but some diatoms remained intact with preserved plastids (Dillon and Davis, 1991; Kawamura et al., 1995, 2005). Similar results were described for Baikal gastropods (Sitnikova et al., 2012).

The aim of the present study was to determine whether gastropod species employ different mechanisms for breaking frustules for large and small diatom cells. Such a feature would allow trophic partitioning of the coexisting species. 


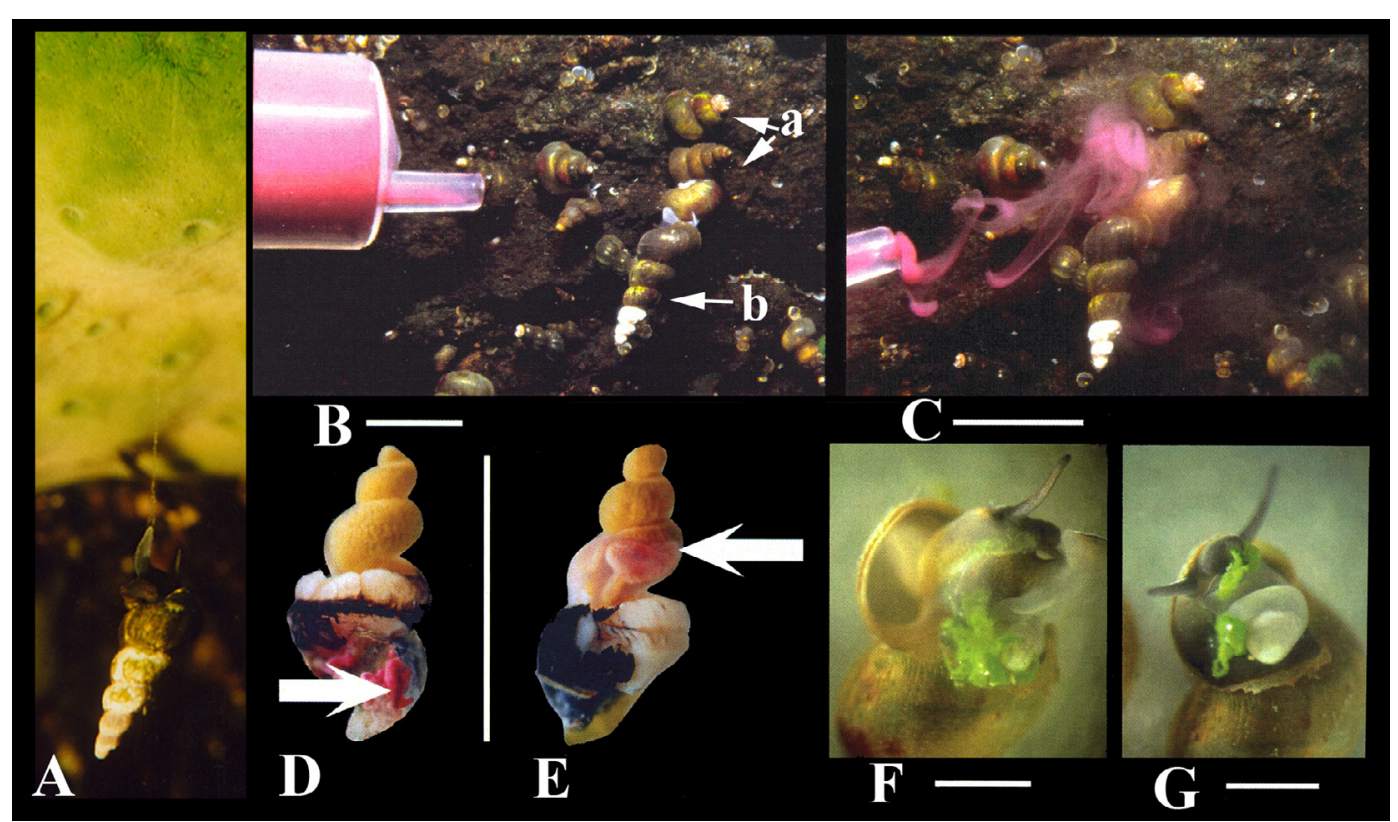

Figure 1

Life habit and feeding mode of Baikal snails. B. turriformis hangs by a byssus thread (A); the focal species $B$. turriformis (a) and T. ciliata (b) before (B) and during the natural experiment; stained yeast is released into the water (C); sectioned $B$. turriformis (shell removed) fixed 5 min after contact with stained yeast; the bolus in front of the snout is intensively colored (D); sectioned B. turriformis (shell removed) fixed 20 min after contact with stained yeast; the stomach is filled with stained yeast (E); $B$. turriformis feeding on Chlorella in the laboratory experiment: the green algae covered by mucus are transported from the mantel cavity (F) and captured by the radula (G). Scale bar: B-E: $1 \mathrm{~cm}, F-G: 2.5 \mathrm{~mm}$. [B-G after Roepstorf et al. (2003)].

\section{MATERIALS AND METHODS}

\section{> OBJECTS OF THE INVESTIGATION}

The species Baicalia turriformis (Dybowski, 1875) (Figure 1A, 2G) and Teratobaikalia ciliata (Dybowski, 1875) (Figure 1B, 2H) (Baicaliidae) are the lithophilous gastropods most common in the south-western littoral zone of Lake Baikal. Both of the snails are able to attach and hang continuously from vertical surfaces and overhanging rock using byssus threads (Figure $1 \mathrm{~A}$ ) (Roepstorf et al., 2003; Sitnikova et al., 2012). Filtering seston, the gastropods passively ingest food particles from the littoral phytoplankton. Roepstorf et al. (2003) studied this process in detail in the field and in laboratory experiments on feeding baicaliids. A stained solution of yeast (Figure 1B-1E) and a Chlorella sp. suspension (Figure $1 \mathrm{~F}-1 \mathrm{G}$ ) were injected into the water, $2-5 \mathrm{~cm}$ away from attached gastropods (Figure 1B-1C). Five minutes after injection a mucus cord of the food appeared from the left side of the mantel cavity (Figure 1F) and was captured by the radular teeth (Figure 1G).

\section{> COLLECTED MATERIAL AND METHODS}

Gastropods were collected randomly by scuba divers in May of 2010 from rocky walls at a

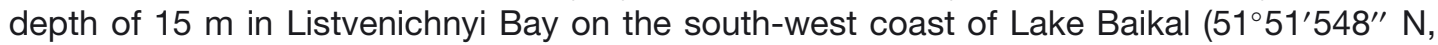
$104^{\circ} 51^{\prime} 308^{\prime \prime}$ E). Only mature adult specimens were collected. Shell sizes of adults are known to vary from 11 to $15 \mathrm{~mm}$ in T. ciliata and from 16 to $22 \mathrm{~mm}$ in B. turriformis (Kozhov, 1936; author's observations). Snails with smaller shell size were excluded from the study because of considerable differences in diets between juveniles and adults (Dillon and Davis, 1991; Dyck et al., 2011). Immediately after sampling, ten specimens of target species were fixed with $4 \%$ 
formaldehyde, and an extra couple of individuals were fixed in $80 \%$ alcohol for scanning electron microscope (SEM) investigation.

Food particles isolated from the anterior gut and feces of each specimen were fixed in $15 \mu \mathrm{L}$ of $4 \%$ formaldehyde, and then divided into three equal parts. Each part of $5 \mu \mathrm{L}$ was placed onto a glass slide and examined under a light microscope (Axiostar plus, Zeiss). The whole slide was scanned to identify microalgae and to count intact/broken diatoms. Only diatom frustule fragments identified at the species level were taken into account; non-identified pieces were ignored. Gut contents and feces of the alcohol-fixed snails were treated with gold and investigated by SEM (FEI Quanta 200). Colored photographs were obtained with a digital camera attached to the microscope.

Twenty individuals of each gastropod species were collected for laboratory experiments. The snails were starved for ten days in an aquarium filled with distilled Baikal water at $6{ }^{\circ} \mathrm{C}$ and natural lighting. Half of the snails were fed with a cell suspension of the cultivated diatom S. acus, cell size range 150-200 $\mu \mathrm{m}$; the diet of the residual snails consisted of $S$. acus cells smaller than $100 \mu \mathrm{m}$. Each snail was fed separately under stereomicroscopic observation. A micropipette was used to place $50 \mu \mathrm{L}$ of cell suspension next to the mantle cavity as viewed from the gill side. Within 5-10 min after capture by the radulae, the bolus was isolated from the anterior gut and fixed with $4 \%$ formaldehyde, prior to the action of the gastric shield and enzymes.

Synedra acus was cultivated in a 96-well flat-bottom plastic plate (Linbro Biomedicals), and each well was filled with $200 \mu \mathrm{L}$ of Diatom Medium (DM) for freshwater algae (Thompson et al., 1988). In each well a clonal culture of $S$. acus was established from an individual "mother" cell of the species isolated from phytoplankton samples of Lake Baikal. The size of the cell in each well was measured under a light microscope (Axiostar plus, Zeiss) using the ImagePro program; the "mother" cells varied from 50 to $200 \mu \mathrm{m}$. The plate was placed in a miniincubator and maintained at $10{ }^{\circ} \mathrm{C}$ and with a $12 \mathrm{~h}: 12 \mathrm{~h}$ (light: dark) photoperiod with an illumination level of 9-15 Einstein $\times \mathrm{m}^{-2} \times \mathrm{s}^{-1}$ (Safonova et al., 2007). After the number of cells in a well reached $\sim 10^{3}$, they were transferred to a 100-mL Erlenmeyer flask for further growth (Shishlyannikov et al., 2011) to provide a sufficient number of $S$. acus cells of a required size to feed the snails. The number of broken cells in any portion of the cultivated S. acus did not exceed $5 \%$.

The samples of proportions of broken large or small cells from the guts of wild caught as well as laboratory-reared $T$. ciliata and $B$. turriformis were tested for normal distribution using the Shapiro-Wilk normality test (Shapiro and Wilk, 1965). The null hypothesis of normality of the distribution was rejected at a confidence level of $<95 \%$. To test the hypothesis of significant differences between the samples the Wilcoxon-Mann-Whitney test was used (Mann and Whitney, 1947) The null hypothesis of equality of the means of two samples was rejected at a confidence level of $<95 \%$ in favor of the alternative. Significant difference between the means of two samples indicates that the individuals providing the compared samples break diatom cells in different ways, i.e. differ in the efficiency with which they break the diatoms.

Data analysis was performed using the $\mathrm{R}$ statistical programming procedure $(\mathrm{R}$ project web page, 2012) and Statistica 6.0 software package.

\section{RESULTS}

Food particles of wild caught specimens of $B$. turriformis and T. ciliata contained, in total, 24 species of microalgae, 21 of them belonging to Bacillariophyta. Two species, Dinobryon cylindricum (Chrysophyta) and Koliella longiseta (Chlorophyta), presented in the gut of both snails, whereas Gymnodinium baicalensis var. minor (Dinophyta) was registered in T. turriformis only The assayed snails shared 12 diatom species, seven species were found in $T$. ciliata only, and finally, two species were detected in B. turriformis only. The chains of 5-25 cells of colonyforming diatom species - planktonic Aulacoseira, Cyclotella and benthic Hannea approaching $200 \mu \mathrm{m}$ in the natural environment - were found as solitary and fragmented cells among food particles of the baicaliids (Figure 2B, 2C). Frustules of the non-colonial diatoms were mostly 


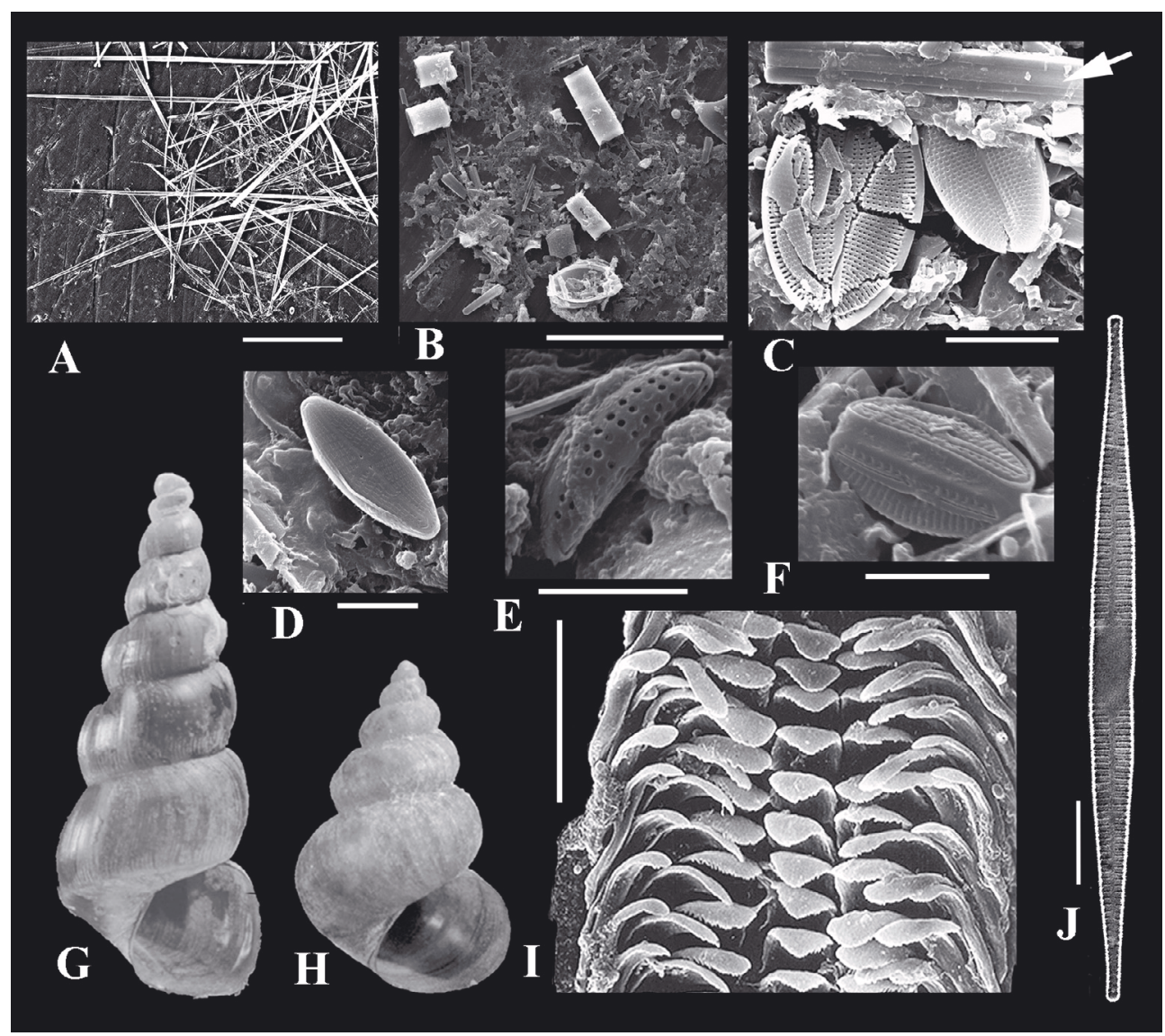

\section{Figure 2}

SEM: cells of cultivated S. acus (A); destroyed colony of diatom Aulocoseira baicalensis, fragments of S. acus and other food particles from snail gut (B); broken frustules of Cocconeius sp. and part of $S$. acus valve (arrow) (C); intact diatoms from snail feces: Navicula sp. (D); Amphora sp. (E); Amphora pediculus $(F)$; entire frustules of $S$. acus $(J)$ from culture; part of the total view of taenioglossan radular teeth, (designations explained in the text) (I). LM : B. turriformis shell of $15.3 \mathrm{~mm}$ in height (G); T. ciliata shell of $9.6 \mathrm{~mm}$ in height (H). Scale bar:A-B: $100 \mu \mathrm{m}, \mathrm{C}: 10 \mu \mathrm{m}, \mathrm{D}, \mathrm{F}: 5 \mu \mathrm{m}, \mathrm{E}: 4 \mu \mathrm{m}, \mathrm{I}: 50 \mu \mathrm{m}, \mathrm{J}: 10 \mu \mathrm{m}$.

fragmented or cracked (Figure 3A-3B). Small-sized diatoms and other microalgae $(10-60 \mu \mathrm{m})$ appeared generally intact (Figure 2D- 2F), often with green chromatophores (Figure 3C).

The diatom S. acus (Figure 2A, 2J) dominated the littoral Baikalian phytoplankton in May, 2010 , as well as being dominant in food particles of both baicaliids. The proportion of $S$. acus in food particles of the species was $45 \%$ and $54 \%$ in B. turriformis and T. ciliata, respectively. In wild caught specimens, the total numbers of fragmented diatom cells were 4,723 $\pm 2,703$ in B. turriformis and $781 \pm 1,061$ - in T. cilata; substantially fewer cells were intact: $829 \pm 1,630$ and $126 \pm 181$, respectively. While the total quantity of intact and fragmented cells differed significantly between the species (see Table I), the percentage of broken frustules in $B$. turriformis and T. ciliata was nearly identical ( $85.8 \%$ and $83.4 \%$, respectively), as the box plots in Figure 4A show.

The experimental feeding with the cultivated diatom $S$. acus showed that some individuals of $T$. ciliata, unlike $B$. turriformis, pushed the food from out of the mantle and did not form a mucus cord.

Examination of the anterior gut content of snails fed with a diet of $S$. acus small cells $(50-100 \mu \mathrm{m})$ showed that most diatoms were undamaged: the proportion of broken cells was practically the same in both gastropod species and did not exceed $26 \%$ (see Table I). 


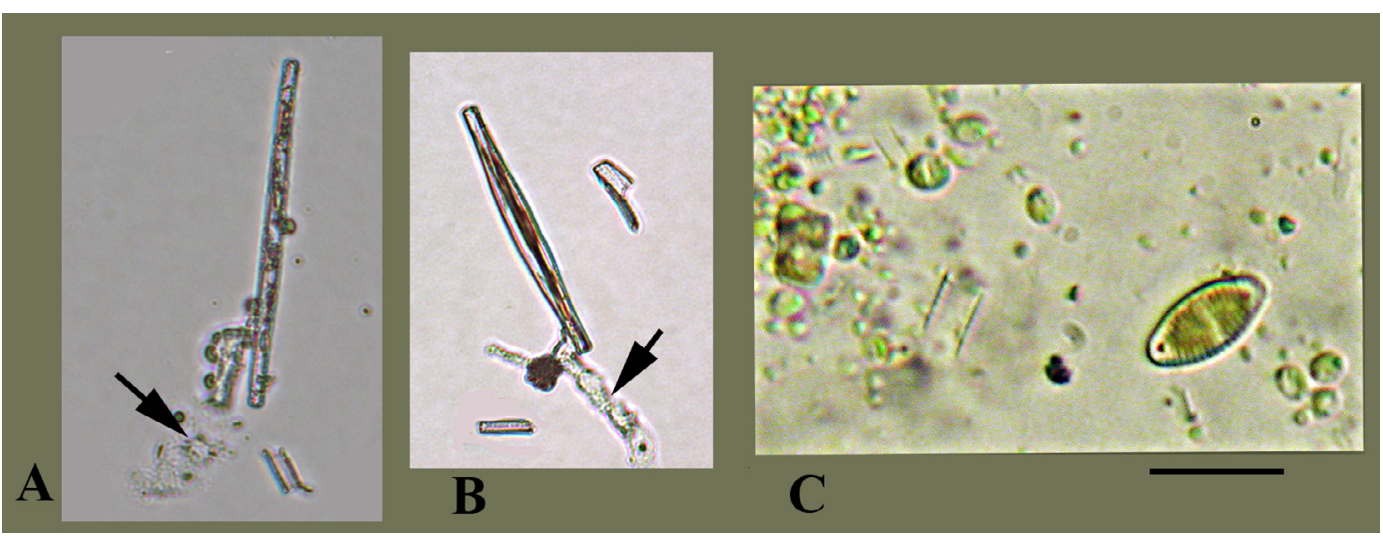

\section{Figure 3}

LM. Diatom cells in snail guts and feces: broken frustules of S. acus with leaked out protoplasts (arrows) $(A-B)$; intact microalgae cells with preserved green chromatophores (C). Scale bar: $50 \mu m$.

\section{Table I}

Results of statistical tests of number and proportions of broken diatom cells found in the gut content of wild caught and laboratory-reared B. turriformis and T. ciliata.

\begin{tabular}{|c|c|c|c|c|}
\hline \multirow{2}{*}{\multicolumn{2}{|c|}{ Species and diets }} & \multirow{2}{*}{$\begin{array}{l}\text { Number of diatom } \\
\text { fragments }\end{array}$} & $W$ & $P$ \\
\hline & & & \multicolumn{2}{|c|}{$\begin{array}{l}\text { Shapiro-W/lk } \\
\text { normality test }\end{array}$} \\
\hline \multirow{2}{*}{\multicolumn{2}{|c|}{$\begin{array}{l}\text { B. turriformis, natural food } \\
\text { T. ciliata, natural food }\end{array}$}} & $(n=9) 4723 \pm 2703$ & 0.76 & 0.08 \\
\hline & & $(n=7) 781 \pm 1061$ & 0.83 & 0.09 \\
\hline \multicolumn{2}{|c|}{ Sample, kind of S. acus diet } & Mean \pm std.dev., $\%$ & & \\
\hline \multirow[t]{2}{*}{ B. turriformis } & large-cell diet, $\bar{X}$ & $(n=10) 88.09 \pm 12.48$ & 0.80 & 0.29 \\
\hline & small-cell diet, $\bar{x}$ & $(n=11) 25.57 \pm 16.28$ & 0.96 & 0.86 \\
\hline \multirow[t]{2}{*}{ T. ciliata } & large-cell diet, $\bar{x}$ & $(n=8) 67.90 \pm 24.90$ & 0.90 & 0.33 \\
\hline & small-cell diet, $\bar{x}$ & $(n=7) 20.67 \pm 15.85$ & 0.95 & 0.74 \\
\hline \multicolumn{3}{|c|}{ Pair-wise comparison of samples of broken cells } & \multicolumn{2}{|c|}{ WMW test, $P<0.95$} \\
\hline \multicolumn{2}{|c|}{ natural food, cell number } & $\bar{X}_{B . t u r r i f o r m i s} / \bar{X}_{T . c i l i a t a}$ & 17 & 0.14 \\
\hline \multicolumn{2}{|c|}{ natural food, percentage } & $\bar{X}_{B . t u r r i f o r m i s} / \bar{X}_{T . c i l i a t a}$ & 42 & 0,3 \\
\hline \multicolumn{2}{|c|}{ S. acus diet, B. turriformis } & $\bar{x}_{\text {large }} / \bar{x}_{\text {small }}$ & 90 & 0.0002 \\
\hline \multicolumn{2}{|c|}{ S. acus diet, T. ciliata, } & $\bar{x}_{\text {large }} / \bar{x}_{\text {small }}$ & 37 & 0.01 \\
\hline \multicolumn{2}{|c|}{ large-sized S. acus diet } & $\bar{X}_{B . t u r r i f o r m i s} / \bar{X}_{T . c i l i a t a}$ & 58 & 0.04 \\
\hline \multicolumn{2}{|c|}{ small-sized S. acus diet } & $\bar{X}_{B . t u r r i f o r m i s} / \bar{X}_{T . c i l i a t a}$ & 31 & 0.5 \\
\hline
\end{tabular}

'Large-sized diet' denotes cells of $S$. acus exceeding $150 \mu \mathrm{m}$; 'small-sized diet' denotes cells of $S$. acus smaller than $100 \mu \mathrm{m}$; ' $n$ ' is the number of analyzed snails.

In the case of a large-cell diet (150-200 $\mu \mathrm{m})$, on average, $88 \%$ and $68 \%$ of cells of $S$. acus appeared in boluses with broken frustules and leaked out protoplasts in $B$. turriformis and in T. ciliata, respectively (Figure 3A, 3C) (see Table I).

According to the Shapiro-Wilk test, the sample means of fragmented cells in wild caught and laboratory-reared snails do not show a normal distribution, excepting two samples, which are nearly normally distributed; therefore the use of the Wilcoxon-Mann-Whitney test was justified. The results of both tests are given in Table I.

There are significant differences in the sample means of both large and small broken cells (see Table I) within each species. In other words, B. turriformis and T. ciliata treat large and small diatoms in distinct ways.

A further comparative result was obtained between the species. The sample means of fragmented cells from the large-cell diet showed a significant difference $(P=0.14)$ between $B$. turriformis and $T$. ciliata while in the small-cell diet the difference was much less $(P=0.5)$. 


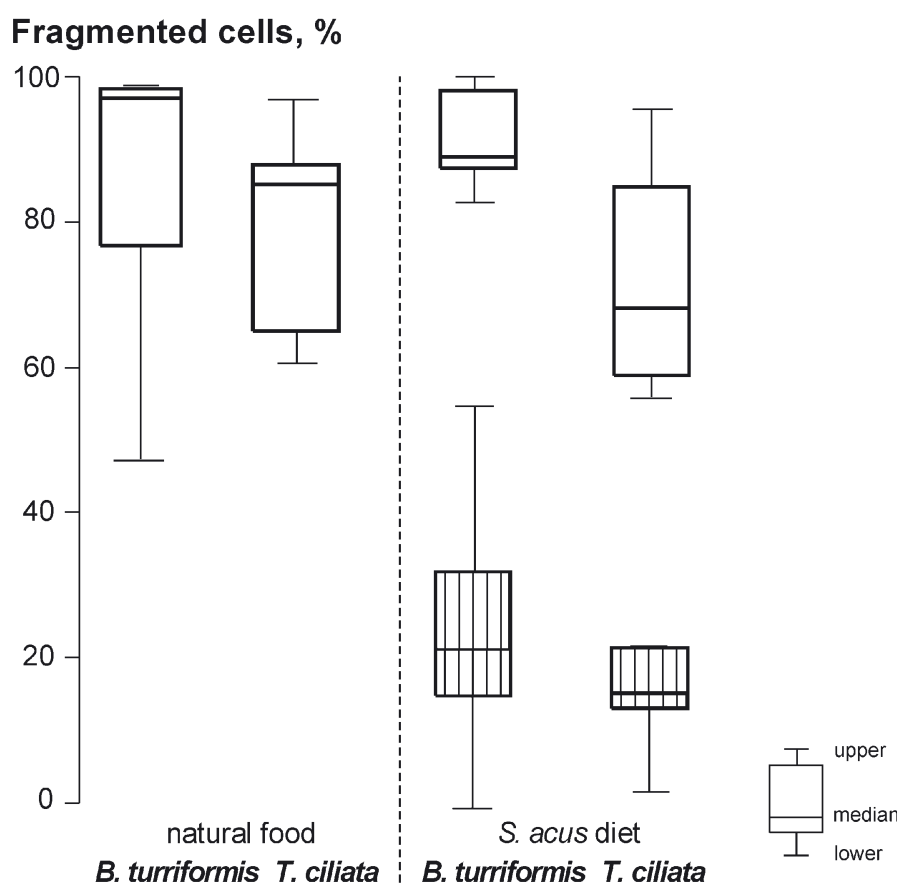

\section{Figure 4}

Box-and-whisker plots showing a range and median of percentage of fragmented diatom cells found in B. turriformis and T. ciliata fed natural food and a diet of small-cell (shaded boxes) or large-cell S. acus.

From measuring 1463 cell fragments in food particles from $B$. turriformis and 1008 from T. ciliata, fed the large-cell diet, we showed that the predominant size of the fragments falls into the range $50-65 \mu \mathrm{m}$ (32\% and 55\% in B. turriformis and T. ciliata, respectively).

In summary, diatom cells, as well as diatom colonies larger than $150 \mu \mathrm{m}$, are fragmented by the radulae of both species of filter-feeding gastropods. The range of the majority of diatom fragments is $50-65 \mu \mathrm{m}$; smaller diatoms can leave the snail gut intact. The differences between $B$. turriformis and $T$. ciliata involve the total number of ingested diatom cells $(B$. turriformis consumes ten times more cells than $T$. ciliata) as well as the means of proportions of breaking large diatom frustules.

\section{DISCUSSION}

The significant difference in the proportions of fragmented large and small diatoms obtained for each gastropod species is explained by known evidence: large diatom cells get broken easily, while small diatoms are more robust and/or difficult to break (Hamm et al., 2003). According to the authors, the silica wall of large diatom cells is crushed at a lower force than that of small cells: diatoms of 260,180 and $30 \mu \mathrm{m}$ can withstand an applied force of 50, 100 and $730 \mu \mathrm{N}$, respectively. The mechanical force necessary to break frustules depends on the size and shape of diatom cells, and also on the direction of the applied force: from above, laterally or across the frustules.

Both filter-feeding T. ciliata and B. turriformis, like the other species of Baicaliidae, have a small $(\sim 1 \mathrm{~mm})$ taenioglossan radula ribbon (Figure $2 \mathrm{l})$ with small teeth $(8-50 \mu \mathrm{m})$; the cutting edge of each tooth is covered with 60 tiny $(<0.4 \mu \mathrm{m})$ cusps (Sitnikova et al., 2012). From our observations, the Baikal gastropods easily break the needle-like frustules of $S$. acus across the protracted narrow ends. The remaining central parts of the frustules of 50-65 $\mu \mathrm{m}$ length dominated the food particles of $B$. turriformis and $T$. ciliata fed the diet of large-cell $S$. acus (Figure 3A, 3B). For some unclear reason, some cells, exceeding the teeth size of the radula, remain intact. Also, another gastropod, the Baikal endemic Benedictia baicalensis with a shell 
of up to $3 \mathrm{~cm}$, a $10-\mathrm{mm}$ taenioglossan radula and teeth larger than $200 \mu \mathrm{m}$, rarely destroys diatom cells, even though it scrapes them mechanically from firm substrates (Sitnikova and Roepstorf, 2004). Dillon and Davis (1991) give a similar example for other mollusc species. Physa sp. has a mussivoglossan radula, an order of magnitude wider than the taenioglossan radulae of Goniobasis proxima and Leptoxis carinata, endowed with tiny cusps. Nevertheless, Synedra cells smaller than $60 \mu \mathrm{m}$ were found intact in the guts of these species. On the whole, regardless of the feeding mechanism (scraping or filtration) or radula type (taenioglossan or mussivoglossan), small diatoms, unlike large ones, often escape destruction by radular teeth. It seems to be more efficient for snails to destroy large diatoms than small ones: more nutrients are acquired by using less force.

We attribute the apparent similarity in the proportions of destroyed diatoms found in the wild caught $T$. ciliata and B. turriformis ( $85 \%$ and $83 \%)$, to the possible small $(<100 \mu \mathrm{m})$ size of cells of the population of $S$. acus dominating the littoral phytoplankton in the spring of 2010 . Snails with small radulae and teeth seem to capture the small food particles more easily than large ones.

The differences both in total number of consumed diatoms and species composition found in the wild caught snails, along with the dissimilarities in the proportions of broken large cells in the laboratory-reared snails, suggest the potential for trophic divergence among species. This is consistent with recent data showing the coexisting $B$. turriformis and $T$. ciliata assimilating different components of the seston - the shared food resource (Sitnikova et al. 2012). The values of the stable isotope, $\delta^{15} \mathrm{~N}$, according to the authors, show that a large part of the diet of $T$. ciliata, unlike $B$. turriformis is of non-plant origin, and consists of protozoa, such as ciliates and flagellates, which do not leave identifiable traces in stomachs. Another observation also suggests a few differences in food preferences of the species. In feeding experiments, individuals of $T$. ciliata, unlike $B$. turriformis often pushed cells of $S$. acus out of the mantle, even after some days of fasting.

Some diatom species fully preserve viability (reproducing, forming colonies) following gut passage through, for example, water penny larvae Psephenus herricki (Peterson and Jones, 2003). Similarly, intact small diatoms with green chromatophores observed in the gut and feces of Baikal gastropods have a chance of returning alive to the environment. It is known that an accumulation of small cells (diatoms become smaller as a result of multiple vegetative divisions) in a diatom population can trigger the sexual process (Chepurnov et al. 2004), which is of vital importance for recovery of their population, which is the main food source of snails. Following Hamm et al. (2003), we consider the reciprocal adaptation of diatoms and phytophagous snails to be an important step in the evolution of the relationships of producers and primary consumers inhabiting the lacustrine littoral zone.

\section{ACKNOWLEDGEMENTS}

We are grateful to the diatom cultivation group of the Cell Ultrastructure laboratory of the Limnological Institute SD RAS for providing the Synedra acus culture. We also thank Ms. Basharina T. for SEM images of the diatom S. acus, Dr P. Roepstorf for the pictures of the snails in nature and the anonymous referees for their valuable advice. This work was partially supported by Budget Research Projects, Nos. VI.50.1.3 and VI.51.1.10 in LIN SD RAS.

\section{REFERENCES}

Bouchet P., Rocroi J.-P., Frýda J., Hausdorf B., Ponder W., Valdés Á. and Warén A., 2005. Classification and nomenclator of gastropod families. Malacologia (Hackenheim, Germany: ConchBooks), 47, 1-397.

Chepurnov V.A., Mann D.G., Sabbe K. and Vyverman W., 2004. Experimental studies on sexual reproduction in diatoms. Int. Rev. Cytol., 237, 91-154. 
Cucker B.E., 1983. Grazing and nutrient interactions in controlling the activity and composition of the epilithic algal community of an arctic lake. Limnol. Oceanogr., 28, 133-141.

Dillon R.T., 2000. The ecology of freshwater mollusks, Cambridge University Press, Cambridge, 509 p.

Dillon R.T. and Davis, K., 1991. The diatoms ingested by freshwater snails: temporal, spatial, and interspecific variation. Hydrobiologia, 210, 233-242.

Dyck M., Roberts R. and Jeffs A., 2011. Assessing alternative grazing-tolerant algae for nursery culture of abalone. Aquaculture, 320, 62-68.

Finkel Z.V, and Kotrc B., 2010. Silica use through time: macroevolutionary change in the morphology of the diatom frustule. Geomicrobiol. J., 27, 596-608.

Glaubrecht M. and von Rintelen T., 2008. The species flocks of lacustrine gastropods: Tylomelaniaon Sulawesi as models in speciation and adaptive radiation. Hydrobiologia, 615, 181-199.

Hamm C., 2005.The evolution of advanced mechanical defenses and potential technological applications of diatom shells. J. Nanosci. Nanotechn., 5, 108-119.

Hamm C., Merkel R., Springer O., Jurkojs P., Maler C., Prectel K. and Smetacek V., 2003. Architecture and material properties of diatom shells provide effective mechanical protection. Nature, 421, 841-843.

Hernández U.A. and Siqueiros-Beltrones D.A., 2010. Non-selective in situ grazing of diatoms by juvenile Green Abalone (Haliotis fulgens Philippi, 1945) in the Baja California Peninsula. Hidrobiólogica (Iztapalapa), 20, 13-19.

Kawamura T., Saido T., Takami H. and Yamashita Y., 1995. Dietary value of benthic diatoms for the growth of post-larval abalone Haliotis discus hannai. J. Exp. Mar. Biol. Ecol., 194, 189-199.

Kawamura T., Roberts R.D. and Takami H., 2005. Importance of periphyton in abalone culture. In: Azim M.E., Nerdegen M.C.J., van Dam A.A. and Beveridge M.C.M. (eds.). Peryphyton: ecology. Exploitation and management, CABI publishing, Wallingford, 269-284.

Kozhov M.M., 1936. Mollusks of Lake Baikal-systematic, distribution, ecology, some data on genesis and history. Proced. Baikal. Limnol. Stat, 8, Nauka, Mosckow-Leningrad, 350 p. (In Russian, summary in German).

Mann H.B. and Whitney D.R., 1947. On a test of whether one of two random variables is stochastically larger than the other. Ann. Math. Statist., 18, 50-60.

Michel E., 1994. Why snails radiate: A review of gastropod evolution in long-lived lakes, both recent and fossil. Arch. Hydrobiol. Beih. Ergebn Limnol., 44, 285-317.

Michel E., 2000. Phylogeny of a gastropod species flock: exploring speciation in Lake Tanganyika in a molecular framework. In Rossiter A. and Kawanabe H. (eds.). Ancient lakes: biodiversity, ecology and evolution, Academic. Moore J.E., London, 275-302.

Peretolchina T.E., Bukin Yu.S., Sitnikova T.Ya. and Sherbakov D.Yu., 2007. Genetic differentiation of the endemic Baikalian mollusk Baicalia carinata (Mollusca: Caenogastropoda). Russian J. Genetics, 43, 1400-1407.

Peterson C.G. and Jones T.L., 2003. Diatom viability in insect faecal material: comparison between two species, Achnanthidium lanceolatum and Synedra ulna. Hydrobiologia, 501, 93-99.

Riera P., 2010. Trophic plasticity of the gastropod Hydrobia ulvae within an intertidal bay (Roscoff, France): a stable isotope evidence. J. Sea Res., 63, 78-83.

Rintelen T. von, Wilson A.B, Meyer A. and Glaubrecht M., 2004. Escalation and trophic specialization drive adaptive radiation of viviparous freshwater gastropods in the ancient lakes on Sulawesi, Indonesia. Proc. R. Soc. Lond., B., 271, 2541-2549.

Roepstorf P., Sitnikova T.Ya., Timoshkin O.A. and Pomazkina G.V., 2003. Observation on stomach contents, food uptake and feeding strategies of endemic Baikalian gastropods. Berliner Palaeobiol., 4, 151-156.

Round F.E., Crawford R.M. and Mann D.G., 1990. The diatoms. Biology and morphology of the genera. Cambridge University Press, Cambridge, $747 \mathrm{p}$.

R-project web page, 2012. R version 2.15.2 (Trick or Treat) has been released on 2012-10-26. http://www.r-project.org

Safonova T.A., Aslamov I.A., Basharina T.N., Chenski A.G., Vereschagin A.L., Glyzina O.Yu and Grachev M.A., 2007. Cultivation and automatic counting of diatom algae cells in multi-well plastic plates. Diatom Res., 22,189-195. 
Shapiro S.S. and Wilk M.B., 1965. An analysis of variance test for normality. Biometrika, 52, 591-611.

Shirokaya A.A., 2003. Post-embrional growth and feeding of Baikal endemic limpets (Gastropoda, Pulmonata, Acroloxidae). Berliner Palaeobiol., 2, 104.

Shishlyannikov S.M., Zakharova Yu.R., Volokitina N.A., Mikhailov I.S., Petrova D.P. and Likhoshway Ye.V., 2011. A procedure for establishing an axenic culture of the diatom Synedra acus subsp. radians (Kütz.) Skabibitsch. from Lake Baikal. Limnol. Oceanogr. Methods, 9, 478-484.

Sitnikova T., Kiyashko S., Maximova N., Pomazkina G., Roepstorf P., Wada E. and Michel E., 2012. Resource partitioning in endemic species of Baikal gastropods indicated by gut content, stable isotopes and radular morphology. Hydrobiologia, 682, 75-90.

Sitnikova T.Ya. and Roepstorf P., 2004. These mollusks live exclusively in Baikal. Sci. first-hands, 1, 84-99.

Sitnikova T.Ya., Shirokaya A.A., Maksimova N.V., Khanayev I.V., Slugina Z.V. and Timoshkin O.A., 2010. Distribution of Gastropoda in the littoral zone of Lake Baikal. Hydrobiol. J., 46, 3-19.

Starobogatov Ya.I. and Sitnikova T.Ya. 1990 The pathways of species formation of the Lake Baikal molluscs. Zhur. Obshchej Biol., 51 499-512. (In Russian).

Thompson A.S., Rhodes J.C. and Pettman I. (eds.), 1988. Culture Collection of Algae and Protozoa. Catalogue of strains, Natural Environment Research and Council, England, 164 p.

Tzikhon-Lukanina E.A., 1987. Feed of aquatic mollusks, Nauka, l̀oskow, 176 p. (In Russian).

Whitlantch R.B. and Obresbski S., 1980. Feeding selectivity and coexistence in two deposit-feeding gastropods. Mar. Biol., 58, 219-225.

Zhang Yu., Gao Ya., Liang Ju., Chen C. and Zhao D., 2010. Benthic diatoms constitute the primary diet of abalone during their early stages of development. Chin. J. Oceanol. Limnol., 28, 1187-1194. 